\title{
Springtime nutrient and phytoplankton dynamics on Georges Bank
}

\author{
David W. Townsend*, Maura Thomas \\ School of Marine Sciences, 5741 Libby Hall, University of Maine, Orono, Maine 04469, USA
}

\begin{abstract}
The dynamics of phytoplankton and nutrients before, during and after the winter-spring bloom on Georges Bank were studied on 6 monthly survey cruises from January to June 1999. We measured hydrography, phytoplankton cell densities, chlorophyll $a_{\text {, dissolved inorganic nutrients }}$ $\left(\mathrm{NO}_{3}+\mathrm{NO}_{2}, \mathrm{NH}_{4}, \mathrm{Si}(\mathrm{OH})_{4}, \mathrm{PO}_{4}\right)$, dissolved organic nitrogen (DON) and phosphorus (DOP), particulate organic carbon (POC) and nitrogen (PON) and total particulate phosphorus (TPP). We present evidence that phytoplankton production may be significant year-round, and that the winter-spring bloom may have started in January. From January to April the phytoplankton was comprised almost exclusively of diatoms, reaching cell densities in March and April of ca. 450 cells ml$^{-1}$; chlorophyll a concentrations exceeded $10 \mathrm{\mu g} \mathrm{l}^{-1}$ in April. Diatoms decreased to relatively low levels in May $(<50 \times$ $10^{3}$ cells l$\left.^{-1}\right)$ and increased again in June $\left(>300 \times 10^{3}\right.$ cells $\left.^{-1}\right)$. Densities of dinoflagellates and nanoflagellates were low $\left(<10 \times 10^{3}\right.$ cells $\left.^{-1}\right)$ from January to April, and increased in May and June to nearly $300 \times 10^{3}$ cells $1^{-1}$. Nitrate + nitrite concentrations in January were $<3 \mu \mathrm{M}$ in the shallow, central portion of the bank and decreased steadily each month. Silicate was also $<3 \mu \mathrm{M}$ over an even larger area of the central bank in January and declined to $<1.5 \mu \mathrm{M}$ over most of the Bank in April. The data suggest that silicate depletion, not DIN, contributed to the cessation of the diatom bloom. Regeneration of silicate occurred in May and June, presumably as a result of rising water temperatures in late spring which increased the dissolution rate of diatom frustules from the earlier diatom bloom. Dissolved organic nitrogen may have been utilized at the start of the winter-spring bloom; concentrations were ca. $14 \mu \mathrm{M}$ in January, dropping to $<6 \mu \mathrm{g} \mathrm{l}^{-1}$ in February, after which DON concentrations steadily rose to $>15 \mathrm{\mu g} \mathrm{l}^{-1}$ in June. Overall micro-and nanoplankton biomass, measured as POC, PON and TPP, increased over the 6 mo period, as did nutritional quality of that biomass as indicated by declining $\mathrm{C}: \mathrm{N}$ ratios. Our results suggest there may have been an increase in the heterotrophic component of the plankton in May and June which coincided with a second burst in diatom abundance. We discuss general features of planktonic production and nutrient dynamics with respect to year-round production on the Bank.
\end{abstract}

KEY WORDS: Nutrient Cycles · Phytoplankton · Primary production · Secondary production silicates · Nitrates · Georges Bank

\section{INTRODUCTION}

The biological productivity of Georges Bank, especially as it pertains to fisheries yields, is thought to be among the highest of any continental shelf sea (Backus 1987), with rates of primary production reported to

\footnotetext{
*E-mail: davidt@maine.edu
}

exceed $400 \mathrm{~g} \mathrm{C} \mathrm{m}^{-2} \mathrm{yr}^{-1}$ in the central portion of the Bank (O'Reilly et al. 1987). That production is known to be seasonal in nature and to exhibit a pronounced late winter-early spring phytoplankton bloom (Riley 1941, Cura 1987, Walsh et al. 1987, Townsend \& Pettigrew 1997), but neither details of the seasonal cycle of primary production nor the dynamics of the spring bloom on Georges Bank are as yet well understood. 
Much of what is known has been summarized by Backus (1987), and in recent years there have been renewed research activities as part of the US Globec Program (Global Ecosystems Dynamics; Wiebe \& Beardsley 1996, Wiebe et al. 2001). New findings include those by Townsend \& Thomas (2001), who reported that silicate is depleted before inorganic nitrogen and may be limiting to diatom production as early as February; regeneration of silicate may contribute to a second pulse in diatom production in late spring, concurrent with a developing nanoflagellate population (Kemper 2000). Inorganic nitrogen, on the other hand, appears to become depleted to levels that could limit phytoplankton growth by April (Townsend \& Thomas 2001). For the remainder of the year, primary production is thought to be fueled largely by recycled nitrogen (Draxler et al. 1985, Horne et al. 1989, 1996). Fluxes of 'new' nitrogen (principally nitrate) delivered to the Bank from deeper waters around its edges appear to be too low to support significant levels of 'new' primary production (cf. Dugdale \& Goering 1967 , Eppley \& Peterson 1979) across an entire submarine bank as large as Georges Bank, prompting Townsend \& Pettigrew (1997) to argue that secondary production is likely to be nitrogen-limited. Consistent with that notion, Sherman et al. (1987) pointed out much earlier that the levels of zooplankton production on Georges Bank are anomalously low compared with rates of primary production; that is, total zooplankton production (microzooplankton plus macrozooplankton) on Georges Bank is about $18 \%$ of primary production, compared with the same ratio in nearby waters in the Gulf of Maine which is $26 \%$ (Cohen \& Grosslein 1987). Thus, the nature of phytoplankton production, its dependence on nutrient dynamics, and their relationships to higher trophic level production on Georges Bank, a marine system renowned for its productive fisheries, remain puzzling in many respects.
This communication presents analyses of more complete data sets for Georges Bank, which encompass the presumed productive period from winter to the summer, with the hope of developing a better sense of how the basic biological oceanography of the Bank operates. Our results reinforce previous observations of the development of the winter-spring phytoplankton bloom on Georges Bank and suggestions of nitrogen and silicate limitation (Townsend \& Pettigrew 1997, Townsend \& Thomas 2001). In addition, we show that there was a species shift from nearly complete dominance of diatoms during the winter-spring bloom, to one of mixed diatoms and flagellates in May and June. During this 6 mo period there was a steady increase in overall plankton biomass and an increase in planktonic food quality (lower particulate C:N ratios). Much of this early summer plankton community depends upon recycled nutrients, especially nitrogen, and we argue that the heterotrophic component of plankton increases in May and June and facilitates the recycling of nitrogen, which drives the majority of planktonic primary production following the winterspring bloom.

\section{MATERIALS AND METHODS}

Water samples were collected at stations sampled during survey cruises to Georges Bank in 1999 as part of the US Globec Program. The cruises were: 11 to 24 January (RV 'Albatross IV'); 11 to 23 February (RV 'Oceanus'); 10 to 23 March (RV 'Oceanus'); 16 to 28 April (RV 'Oceanus'); 19 to 27 May (RV 'Albatross IV'); 14 to 24 June (RV 'Albatross IV'). CTD casts for vertical profiles of temperature and salinity were made at 41 standard stations (Fig. 1); these hydrographic data were collected and processed by Dr. D. Mountain and M. Taylor of the Northeast Fisheries Science Center,

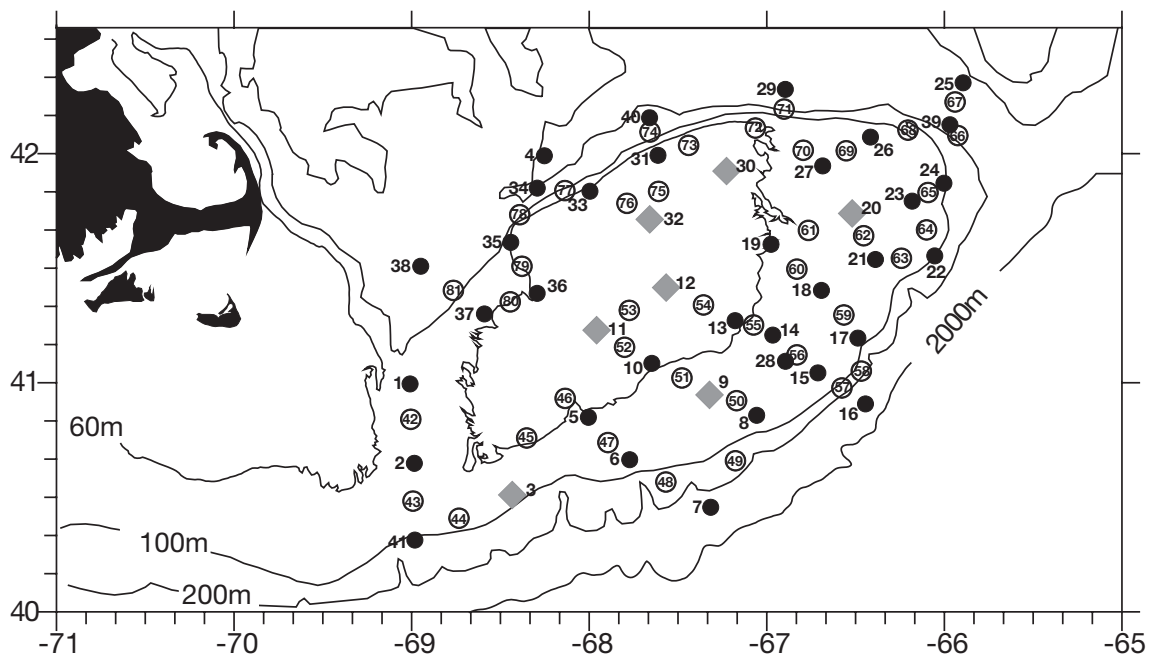

Fig. 1. Map of the Georges Bank area showing positions (abscissa = longitude, , ordinate $=$ latitude) of stations sampled in 1999: 41 standard stations, and the intermediate stations (Nos. 42-81). The 60, 100, 200 and $2000 \mathrm{~m}$ isobaths are given. $(\diamond)$ phytoplankton cell-count stations 
Woods Hole, Massachusetts. Water samples for analyses of nutrients and phytoplankton were collected during the same casts using Niskin bottles mounted on a rosette sampler. On all cruises we collected additional near-surface water samples (1 to $2 \mathrm{~m}$ depth) at positions halfway between the regular stations; these stations are numbered 42 to 81 (Fig. 1).

Samples for dissolved inorganic nutrients were filtered through $0.45 \mu \mathrm{m}$ Millipore cellulose acetate membrane filters, after first flushing the filters with sample water. Samples were then frozen in $20 \mathrm{ml}$ polyethylene scintillation vials by first placing the vials in a seawater-ice bath for about $10 \mathrm{~min}$. Analyses for $\mathrm{NO}_{3}+$ $\mathrm{NO}_{2}, \mathrm{NH}_{4}, \mathrm{Si}(\mathrm{OH})_{4}$, and $\mathrm{PO}_{4}$ were made on shore after the cruise, using a Technicon II AutoAnalyzer and standard techniques (Whitledge et al. 1986). Particulate organic carbon (POC) and nitrogen (PON) concentrations were determined at standard stations (1 to 41 ; Fig. 1) at 2 and $20 \mathrm{~m}$ depth, selected arbitrarily. Samples were collected by filtering $500 \mathrm{ml}$ onto a preashed GF/F filter; the sample was frozen, and later fumed with $\mathrm{HCl}$ to remove inorganic carbon before analysis with a Control Equipment Model 240-XA CHN analyzer (Parsons et al. 1984). Samples for total particulate phosphorus (TPP) were collected as for POC and PON (but $200 \mathrm{ml}$ were filtered) and the filters were frozen at sea and later analyzed using a modification of the method of Solórzano \& Sharp (1980b). The filter was oxidized at $530^{\circ} \mathrm{C}$ for $2 \mathrm{~h}$, digested in $1 \mathrm{ml}$ $10 \%$ HCL for $24 \mathrm{~h}_{i} 19 \mathrm{ml}$ deionized water were then added; the sample was subsequently analyzed as for orthophosphate on the AutoAnalyzer. Concentrations of dissolved organic nitrogen (DON) and phosphorus (DOP) were determined by measuring total $\mathrm{N}$ and total P by the methods of Solórzano \& Sharp (1980a,b) and subtracting the total concentrations of dissolved inorganic nitrogen and phosphorus; these samples were also collected at 2 and $20 \mathrm{~m}$ at the 41 standard stations. Phytoplankton chlorophyll a was measured fluorometrically on discrete water samples (Parsons et al. 1984). Samples of $100 \mathrm{ml}$ were filtered onto GF/F filters, extracted in $90 \%$ acetone in a freezer $\left(-18^{\circ} \mathrm{C}\right)$ for at least $6 \mathrm{~h}$, and then analyzed at sea using a Turner Model 10 fluorometer.

Surface-water samples of $100 \mathrm{ml}$ for phytoplankton cell densities and taxonomic composition were collected at 7 stations and preserved in Lugol iodine solution. The 7 stations were selected to represent the phytoplankton community on the Bank (Stns 3, 9, 11, 12, 20, 30 and 32; Fig. 1). A $50 \mathrm{ml}$ subsample was allowed to settle in a graduated cylinder for 24 to $48 \mathrm{~h}$, after which the top $40 \mathrm{ml}$ were drawn off leaving a $5 \times$ concentrated sample. A $1.3 \mathrm{ml}$ subsample of the concentrated sample was placed in a counting chamber and enumerated at either 100 or $400 \times$ magnification using a Nikon TMS inverted microscope. A minimum of 100 cells was enumerated for each station sample; on average, 200 to 700 cells were enumerated. The cells were identified as diatoms, dinoflagellates or other flagellates (nanoflagellates); lower taxonomic identifications were made only to record the dominant genera and species in each sample.

\section{RESULTS}

Seasonal distributions of near-surface temperature, salinity, chlorophyll $a$, nitrate + nitrite, silicate, phosphate and ammonium are presented as contour plots in Figs. 2 to 8 respectively.

Coldest surface water temperatures were not reached until March 1999, when temperatures were generally 4.5 to $5.5^{\circ} \mathrm{C}$ over much of the top of the Bank (Fig. 2). Slightly colder water could be seen moving onto the Bank as part of an intrusion of Scotian shelf water, but that intrusion was confined to the easternmost edge of the Bank. The characteristic lower salinity of the Scotian shelf water is also evident in Fig. 3. Slight warming of the top of the Bank only became evident during April, when surface temperatures were on average $>5.5^{\circ} \mathrm{C}$; however, during March and April much warmer (and saltier) surface waters could be seen along the southern flank of the Bank in association with slope water. The rate of springtime warming on the Bank accelerated between April and May, when temperatures rose by an average of 3 to $4^{\circ} \mathrm{C}$. Temperatures rose another 3 to $4^{\circ} \mathrm{C}$ between May and June, reaching a bank-wide average of about $12^{\circ} \mathrm{C}$ in June. Vertical mixing by tides helped maintain a fairly uniform distribution of water properties throughout the water column over the entire Bank until May, when surface warming over deeper waters began to develop approximately along the $100 \mathrm{~m}$ isobath; this was most apparent in the southernmost portions of our sampling domain. Because of the nearly uniform vertical distributions of water properties, we refer here primarily to surface samples; cases of non-uniform vertical distributions are noted when appropriate.

Concentrations of chlorophyll $a$ in the surface waters in January were greater than $1 \mathrm{\mu g} \mathrm{l}^{-1}$ at most stations on the top of the Bank and $>2 \mu \mathrm{g} \mathrm{l}^{-1}$ at some (Fig. 4). By February, chlorophyll concentrations over the central portions of the Bank were $>3 \mu \mathrm{g} \mathrm{l}^{-1}$ (and $>7 \mu \mathrm{g} \mathrm{l}^{-1}$ at Stns 52 and 53) and increased to $>5 \mu \mathrm{g} \mathrm{l}^{-1}$ over much of the Bank in March and April, with overall highest chlorophyll concentrations appearing in April (>14 $\mu \mathrm{g} \mathrm{l}^{-1}$ at $\operatorname{Stn} 70$ ).

The concentrations of nitrate + nitrite over the central portions of the Bank became steadily depleted between January and June, in keeping with the general 

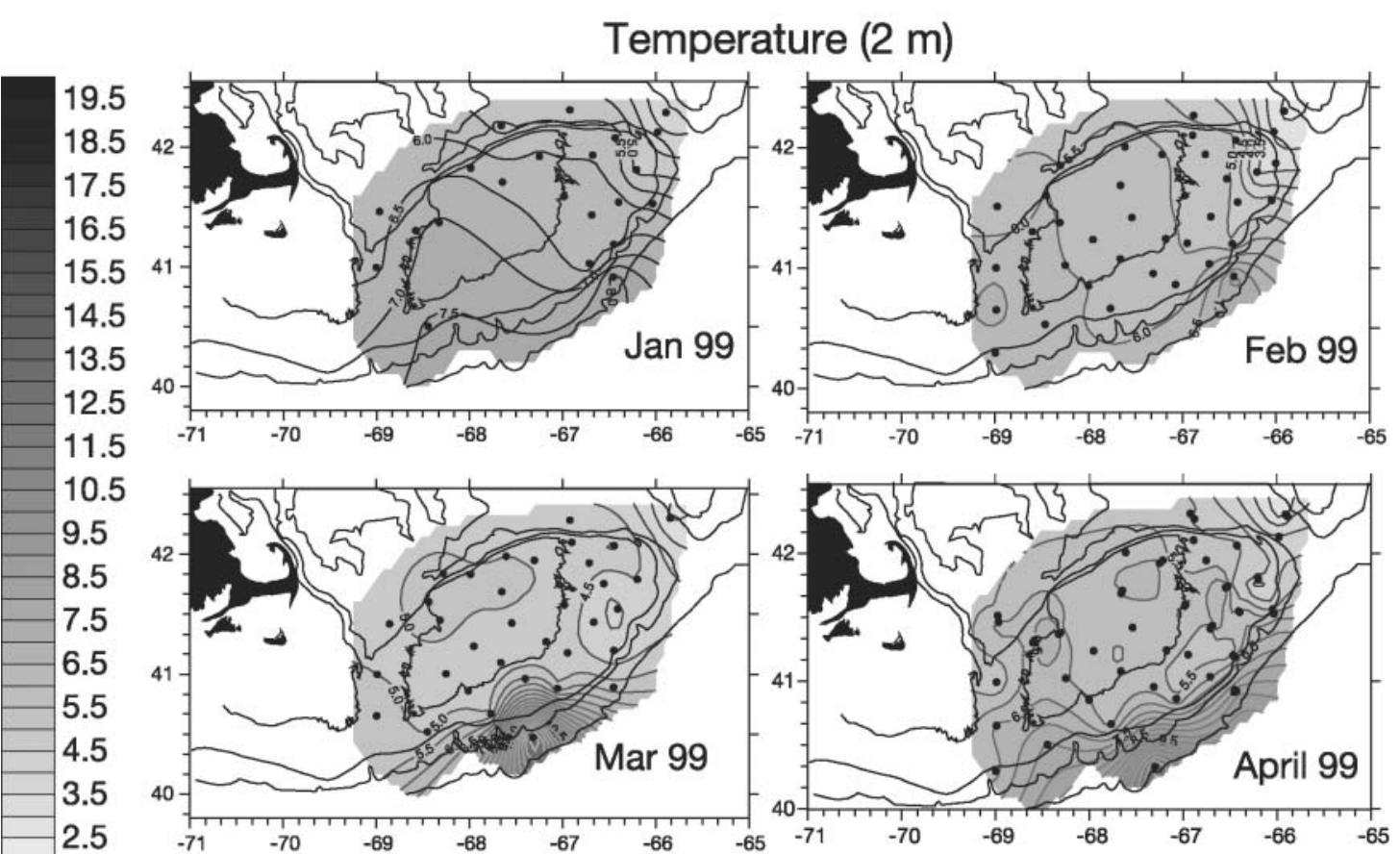

1.5
0.5

$\left({ }^{\circ} \mathrm{C}\right)$
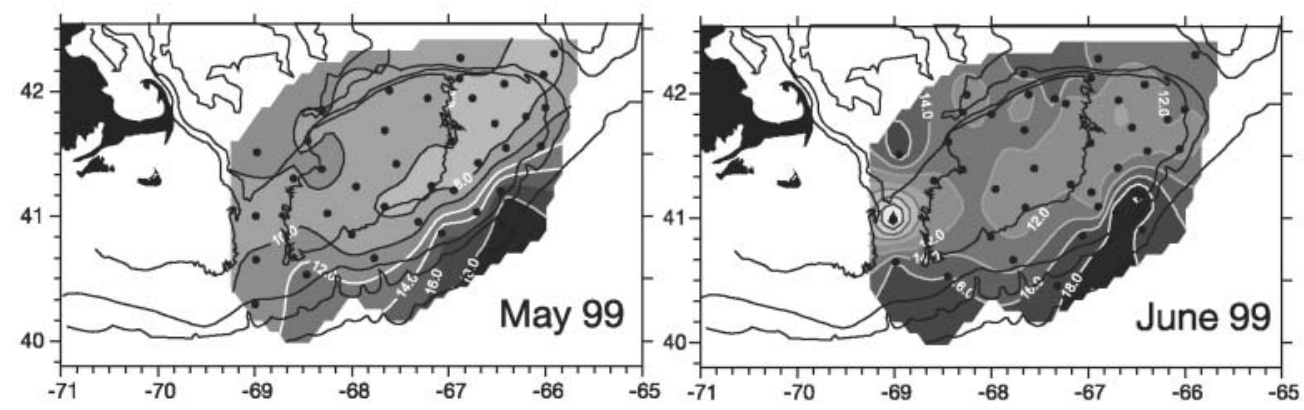

Fig. 2. Areal contour plots of surface temperatures during 1999 for the January to June cruises. Here and in Figs. 3 to 8 \& 10 stations are indicated by dots, and abscissa and ordinate are longitude and latitude respectively

pattern of phytoplankton growth as revealed by chlorophyll distributions (Fig. 5). Concentrations of nitrate + nitrite in January were lowest $(<1 \mu \mathrm{M})$ at Stn 10 on the central part of the Bank (Fig. 1), but were higher over most of the remainder of the Bank. By February, the patch of lowest nitrate + nitrite concentrations had become slightly larger in areal extent (Fig. 5), but the area encompassed by the $5.0 \mu \mathrm{M}$ nitrate + nitrite concentration did not appear to change appreciably between January and February. Overall, dissolved inorganic nitrogen (nitrate, nitrite and ammonium) did not appear to be contributing significantly to the developing phytoplankton population during this initial period. By April, the shallowest central portions of the Bank were becoming depleted in nitrate + nitrite when much of the Bank had surface concentrations $<2 \mu \mathrm{M}$. In May, only the northeast peak of the Bank and waters to the southwest (downstream) exhibited detectible levels of nitrate + nitrite; by June, only 1 station exhibited detectable levels. The shallower stations (inside the $60 \mathrm{~m}$ isobath) were generally vertically well-mixed, as indicated by isothermal temperature and isohaline salinity profiles, and consequently they did not exhibit vertical gradients in nutrient concentrations throughout the 6 mo period.

Silicate became limiting to the winter-spring diatom bloom before nitrogen (Fig. 6). In January, silicate levels were $<3 \mu \mathrm{M}$ over most of the top of the Bank, and a large area of the Bank exhibited concentrations $<2 \mu \mathrm{M}$. The pattern of silicate depletion continued through February and March, and by April concentrations were undetectable at all but a few stations which were located along the southern flank. Perhaps by May, and certainly by June, there was clear evidence of a new flux of silicate over parts of the northern Bank; these increases were not associated with concomitant 


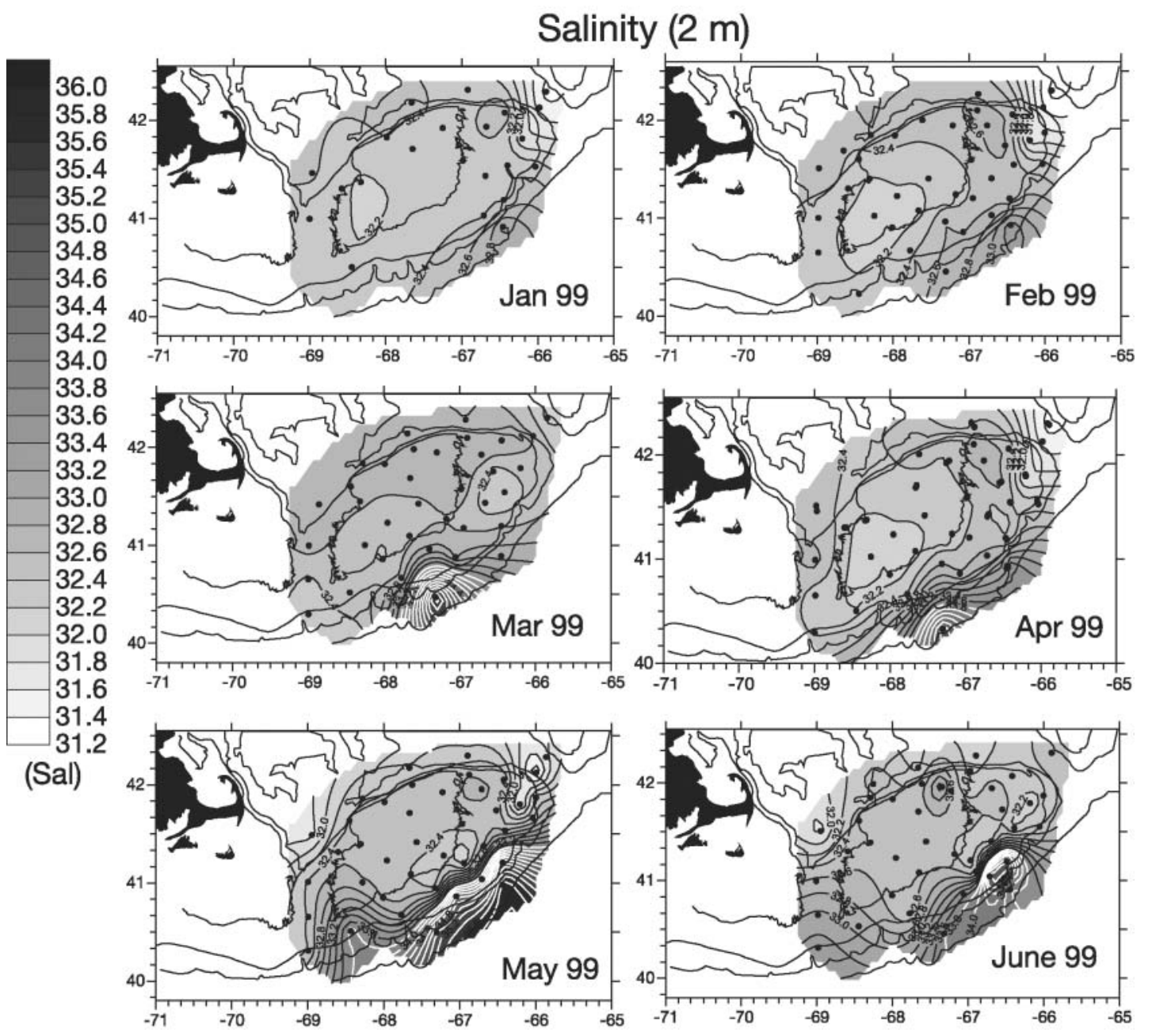

Fig. 3. Areal contour plots of surface salinity during 1999 for the January to June cruises

and coherent increases in nitrate + nitrite, nor with colder and saltier water, as would be the case if the flux were the result of upwelling. Instead, these fluxes were probably associated with a regeneration of silicate on the Bank, as has been observed earlier (Kemper 2000, Townsend \& Thomas 2001).

Concentrations of phosphate in surface waters in January were mostly in the range of ca. 0.5 to $1.0 \mu \mathrm{M}$ (Fig. 7), and showed a steady decrease from January to June. The decrease was most apparent for the central portions of the Bank, similar to that of nitrate + nitrite and silicate. In May and June there was evidence of slightly higher concentrations in the vicinity of the northeast peak, consistent with upwelling and spreading of Gulf of Maine water into that area.

Surface concentrations of ammonium rarely exceeded $2.0 \mu \mathrm{M}$, and then only in isolated patches. Apart from these patches, the concentrations of ammonium reached a Bank-wide maximum in June, with average concentrations of 0.3 to $0.4 \mu \mathrm{M}$ (Fig. 8).
Densities of diatoms, dinoflagellates and 'other' phytoplankton groups (mainly nanoflagellates) at 7 stations, selected to be representative of the Bank, are given in Fig. 9. Four stations are located on the top of the Bank, inside the $60 \mathrm{~m}$ isobath (Stns 11, 12, 30 and 32 ), and 3 are located along the eastern and southern flank between the 60 and $100 \mathrm{~m}$ isobaths (Stns 3, 9 and 20). The stations on the top of the Bank exhibited the highest densities of diatoms during the January to April period; densities were $>450 \times 10^{3}$ cells $1^{-1}$ in February and March at Stn 12 . The dominant taxa in January were the diatoms Thalassiosira spp. On average, diatom densities on the top of the Bank declined to their lowest densities in May, and subsequently increased again in June. Cell densities at the 3 deeperwater, flank stations (Stns 3,9 and 20) did not show a pronounced winter-spring bloom compared with the top of the Bank, which most probably resulted from light-limitation at those stations because of tidal mixing and greater bottom depths. On average, highest 

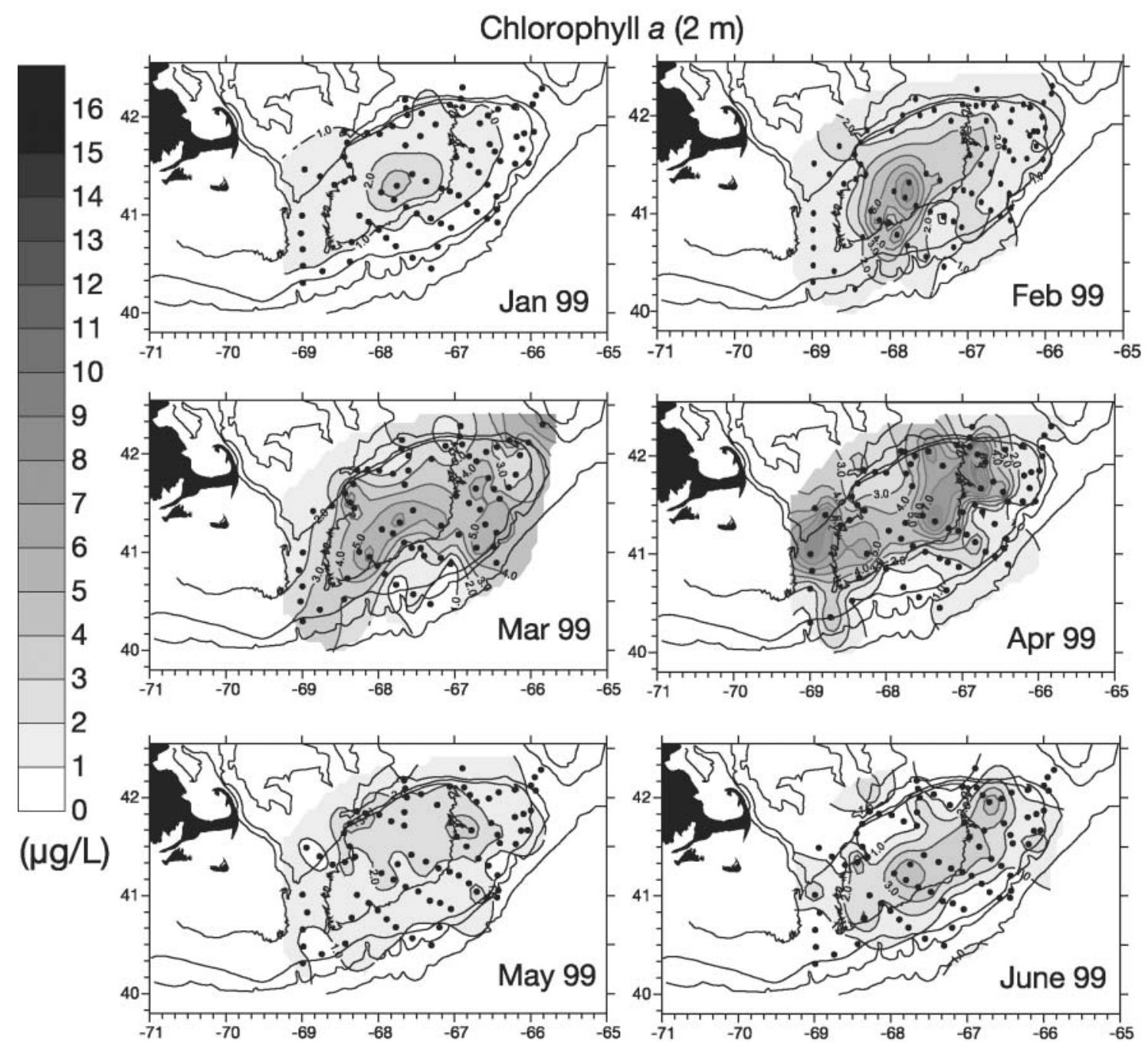

Fig. 4. Areal contour plots of surface chlorophyll (extracted chlorophyll a) during 1999 for the January to June cruises. (•) stations

diatom densities at these stations occurred during the May and June period. The dominant diatoms throughout the region were Chaeotoceros spp., Guinardia spp., Thalassionema spp., and a variety of Nitschialike pennates. Cell densities of dinoflagellates and other groups were generally very low from January to April $\left(<10 \times 10^{3}\right.$ cells $\left.^{-1}\right)$, especially at the 4 shallower stations, and began to increase in May and June in a temporal pattern similar to what one would expect in terms of phytoplankton species succession. Dominant dinoflagellates were primarily Ceratium spp., plus Peridinium spp. and Prorocentrum spp. at somewhat lower densities. The 'other' group comprised almost exclusively nanoflagellates, especially the genus Pyramimonas (6 to $10 \mu \mathrm{m}$ ), which dominated the plankton in May at Stn 9 (ca. $300 \times 10^{3}$ cells $\mathrm{l}^{-1}$ ). Primarily because of the Lugol-stained samples, we were unable to determine reliably which cells might have possessed chloroplasts and which were more likely to be heterotrophic.

Concentrations of dissolved organic nitrogen (Fig. 10) showed initially high values in January, averaging $14.0 \mu \mathrm{M}$ nitrogen (average of 2 and $20 \mathrm{~m}$ samples at all 41 standard stations), but dropped to an average of $5.5 \mu \mathrm{M}$ the next month. The DON concentrations then increased each month to an average concentration of $15.3 \mu \mathrm{M}$ in June. The concentrations of dissolved organic phosphorus (not shown) were extremely low from January to April, when they were not significantly different from zero. In May the concentrations averaged only $0.2 \mu \mathrm{M}$, and dropped to half that value in June.

The areal distributions of particulate organic carbon and nitrogen, and total particulate phosphorus were similar to that of chlorophyll, with elevated concentrations centered mostly on the top of the Bank through 


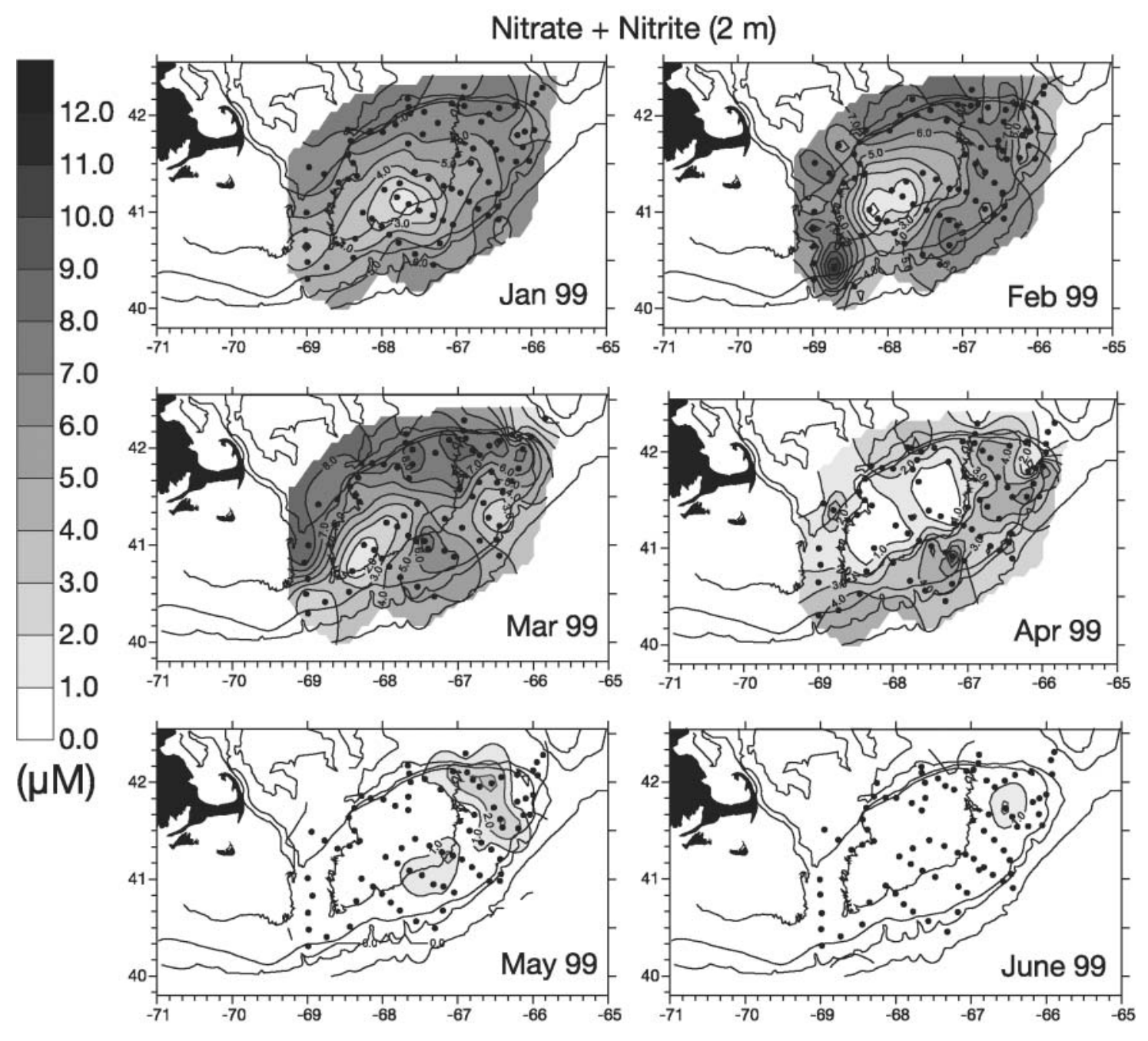

Fig. 5. Areal contour plots of surface nitrate + nitrite during 1999 for the January to June cruises. (•) stations

April. The distributions were more patchy in May and June, with stations both on the top of the Bank and along the flanks and edges exhibiting elevated concentrations. Concentrations of POC, PON and TPP (Fig. 11) increased from January to June. This increase in particulate biomass measures stands in contrast to the trend for chlorophyll (Fig. 4), which reached a peak in April, dropped to lower concentrations in May, and then increased again in June. Concentrations of particulate organic nitrogen and carbon, and total particulate phosphorus taken together would represent total micro- and nanoplankton biomass (Fig. 11). These biomass measures did not undergo great changes in their proportions to each other over the 6 mo sampling period; i.e. they can be plotted on scales that do not need to be adjusted for each month. In general, the ratios of POC:PON:TTP are approximately in the proportions of $77 \mathrm{C}: 18 \mathrm{~N}: 1 \mathrm{P}$ by weight (using the $y$-axes in Fig. 11 as overall 6 mo averages), which is a departure from the Redfield ratio of 40C:7N:1P (106C:16N:1P by atoms). Nitrogen is thus enriched relative to carbon and phosphorus in these samples, while phosphorus is low relative to nitrogen and carbon. These departures would be expected if our samples included heterotrophic organisms; for example, Elser et al. (1996) showed that protozoans can have atomic N:P ratios of 30 to 50 (13 to 22 by weight); this is similar to our results.

Ratios of average POC:PON from January to May (Fig. 12) show values close to, but slightly greater than the Redfield ratio, with values in June dropping below the Redfield ratio. The negative slope $(-0.26)$ of the $\mathrm{C}: \mathrm{N}$ ratios over the 6 mo period is significant $(\mathrm{p}<0.05$; Fig. 12). The lowest C:N ratios, which indicate nitrogen-enrichment in the particulate organic material, occurred in June, at the time of overall greatest particulate biomass (Fig. 11).

Linear regression lines fitted to POC versus chlorophyll a for each month (2 and 20 m samples for Stns 1 


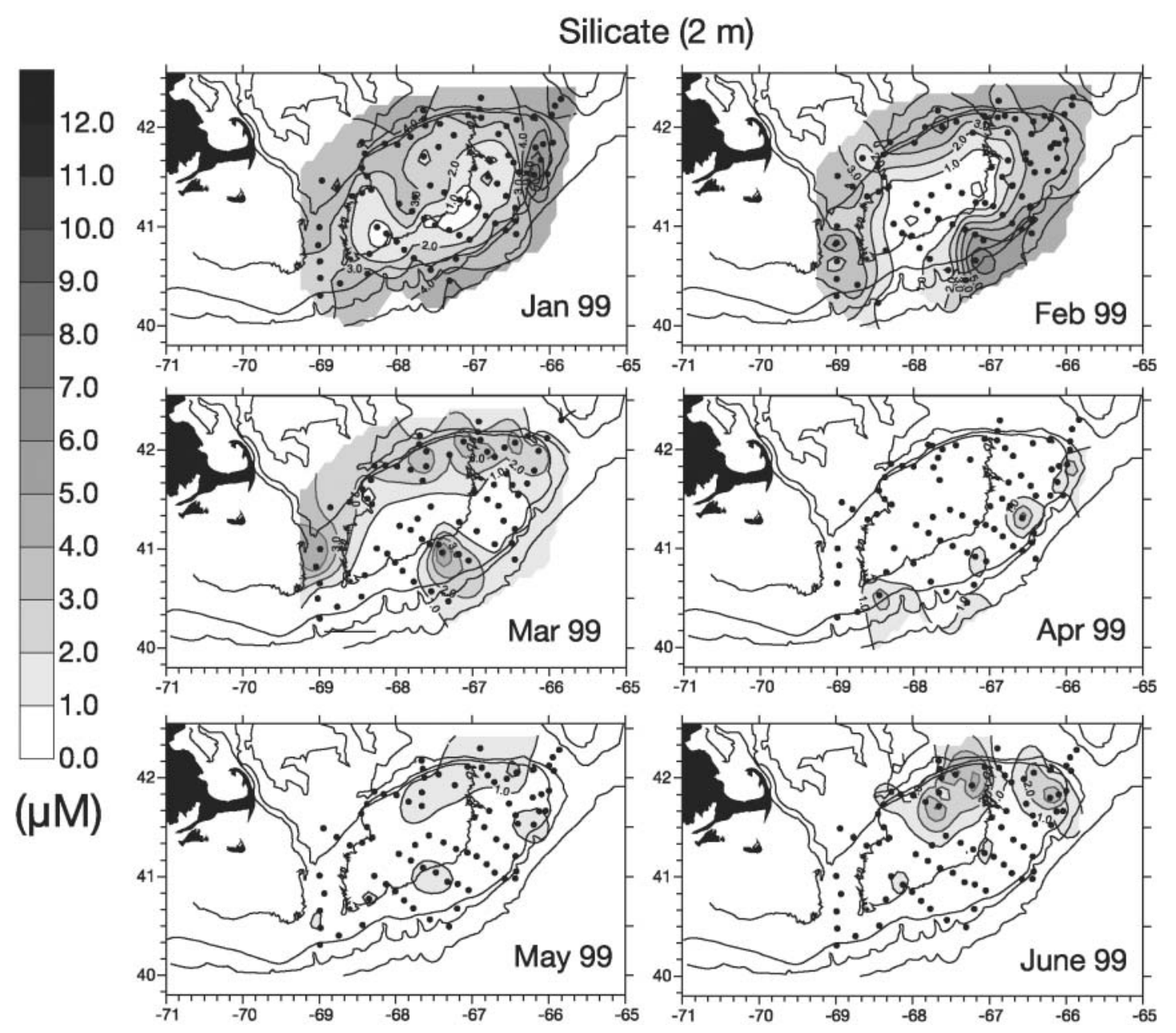

Fig. 6. Areal contour plots of surface silicate during 1999 for the January to June cruises. (•) stations

to 41) have non-zero $y$-intercepts of between 71 and $187 \mathrm{Mg} \mathrm{l}^{-1}$ POC (Fig. 13). These $y$-intercepts are assumed to represent the non-photosynthetic component of the particulate biomass, which includes both living (heterotrophic) and non-living detrital particulate material; this biomass fraction generally increased from January to June, with the exception of a dip in May (Fig. 14). While there is a great deal of scatter in the data (Fig. 13). Table 1 shows that significant differences $(p<0.05)$ in the $y$-intercepts plotted in Fig. 14 exist between 3 monthly pairings: January and March, January and April, and May and June.

The slopes of the POC versus chlorophyll a regression lines (Fig. 13) provide estimates of the carbon-tochlorophyll ratio, ranging between 34 and 66 for all months except May, which had a slope of 100 (Fig. 14). Because these ratios are the slopes of the regression lines in Fig. 13, they do not include heterotrophic nor detrital organic carbon; thus, we have estimates of phytoplankton-specific carbon-to-chlorophyll ratios. Changes in these ratios between months (Fig. 14) can be interpreted to indicate changes in the relative phytoplankton growth rates, with low ratios corresponding to high growth rates, such as we see in the February to April period that encompasses the diatom bloom. Table 2 indicates that the slopes of the regression lines in Fig. 13 (phytoplankton carbon-to-chlorophyll ratios) for January, May and June, which represents a low growth period, are statistically different ( $p<0.05)$ from the February, March and April lines, which represent a high growth period.

\section{DISCUSSION}

Recent studies have demonstrated that the winterspring phytoplankton bloom on Georges Bank starts as early as February and depletes inorganic nutrients by April (Townsend \& Pettigrew 1997, Townsend \& Thomas 2001). Our results indicate that the bloom may start even earlier, in that we observed a patch of elevated chlorophyll concentrations on the top of the 


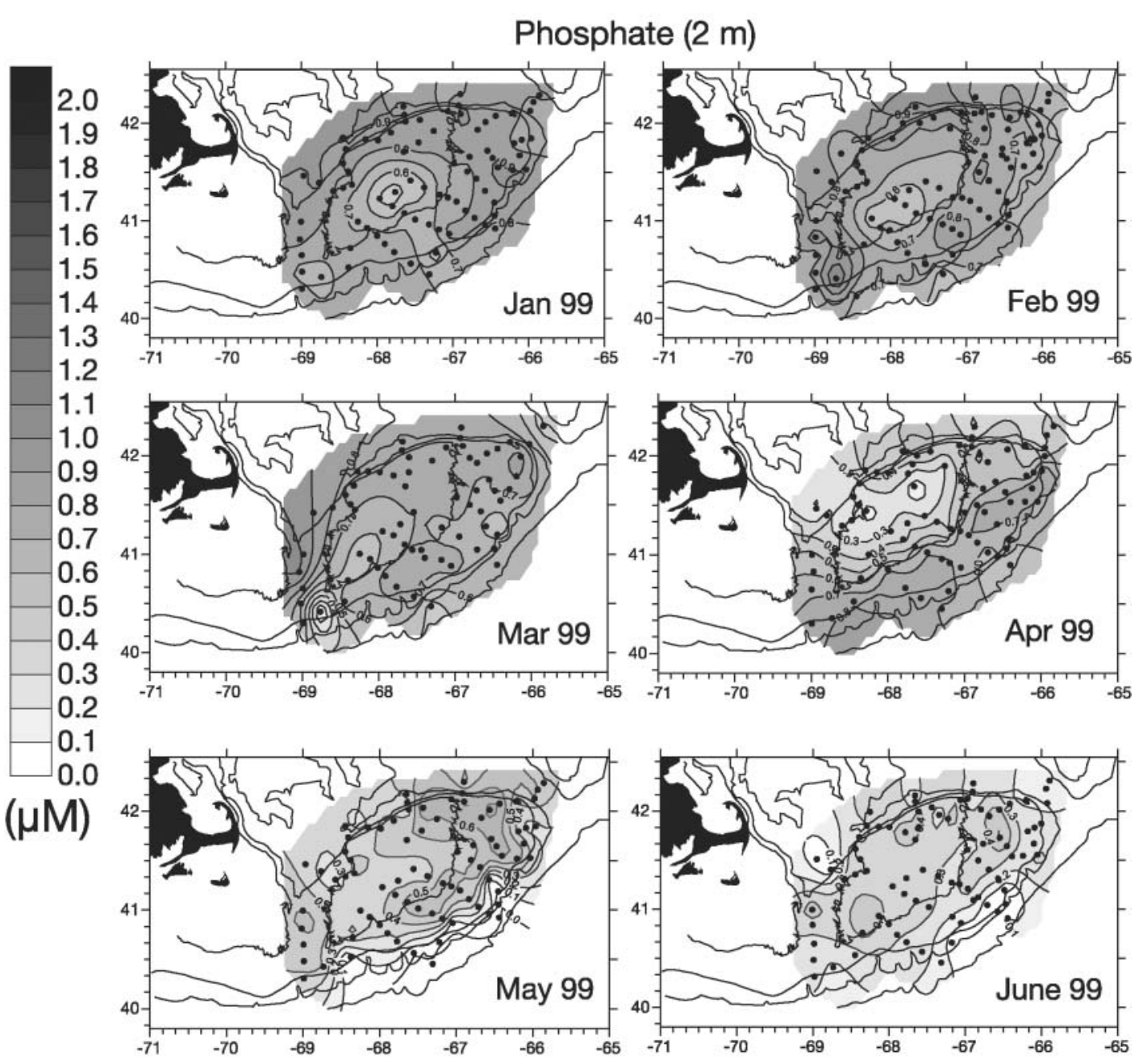

Fig. 7. Areal contour plots of surface phosphate during 1999 for the January to June cruises. (•) stations

Bank in January of 1999, at which time the nutrient distributions, especially silicate, showed evidence of already having been drawn down. Diatom cell densities in January ranged between 50 and $>180 \times 10^{3}$ cells $\mathrm{l}^{-1}$ (at the stations where chlorophyll concentrations were high, Stns 11 \& 12). This indication of relatively high diatom production rates as early as January may not represent the actual initiation of the winter-spring bloom, however. We cannot rule out the possibility that our survey in January was in fact describing some combination of incomplete wintertime nutrient replenishment on Georges Bank, driven by winter mixing and in situ regeneration, and a continuing low-but nonetheless significant-level of winter primary production. Together, these could explain the relatively low nutrient concentrations over much of the Bank prior to the onset of the winter-spring bloom. With respect to nutrient replenishment, it is possible that the central portions of the Bank are too far away from the deeper, nutrient-rich waters beyond the Bank's edges for complete replenishment to occur over the late fall and winter. Because much of Georges Bank is very shallow (the average depth inside the $60 \mathrm{~m}$ isobath illustrated in Fig. 1 is $>25 \mathrm{~m}$ ) we would expect that primary production would not be light-limited. That is, vertical thermal stratification and water-column stability (sensu Townsend et al. 1994) are not requisites; the shallow bottom serves as the base of the upper mixed layer. If the water transparency is clear enough, and the ambient light levels high enough, then net positive photosynthesis is possible. Using values of the diffuse attenuation coefficient collected in February 1997 $\left(0.18 \mathrm{~m}^{-1}\right.$; Townsend \& Xu 1997) and calculations given in Townsend \& Spinrad (1986), we see that the critical depth for net positive phytoplankton production is always deeper than the bottom, even on the winter solstice. Thus, it would appear possible that phytoplankton production on the shallower, central portions of Georges Bank may be maintained at a low but significant level year-round, and at a rate sufficient to keep 

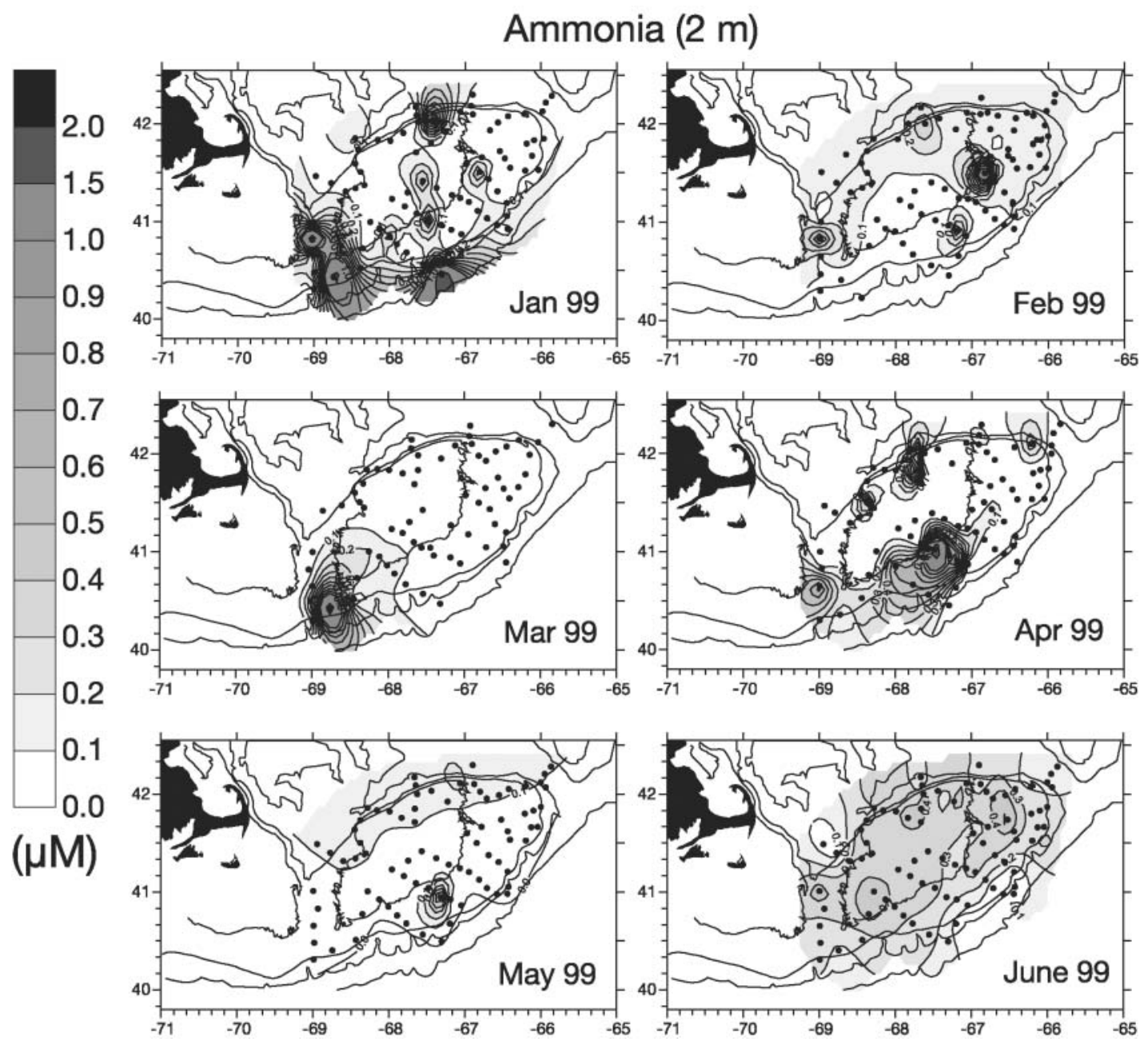

Fig. 8. Areal contour plots of surface ammonium during 1999 for the January to June cruises. (•) stations

wintertime inorganic nutrient levels low. On the other hand, presumably because of tidal mixing and light limitation, waters between the 60 and $100 \mathrm{~m}$ isobaths did not exhibit such a pronounced winter-spring diatom bloom (Figs. 4 \& 9).

Regardless of wintertime levels of primary production on Georges Bank, we clearly observed a pronounced winter-spring phytoplankton bloom, especially in waters on the top of the Bank and inside the $60 \mathrm{~m}$ isobath. At its height, chlorophyll concentrations exceeded $10 \mu \mathrm{g} \mathrm{l}^{-1}$, which was almost exclusively attributable to diatoms. Following the bloom, we observed a shift in phytoplankton species composition, from a winter-spring dominance of diatoms (again, especially on the top of the Bank), to diminishing densities of diatoms in May (except at Stn 3), followed by increasing densities of diatoms in June; other flagellates began to increase in May. Cura (1987) noted the increasing importance of dinoflagellates in early summer, but based on his own samples and a review of ear- lier work in the area, he made no mention of the May period of very low diatom densities. This phenomenon of decreasing diatom densities reaching a minimum in May is an apparent result of silicate becoming depleted over the top of the Bank prior to nitrogen, and therefore limiting diatom growth. The reason is that source waters available for mixing with the waters on top of Georges Bank contain approximately 4 to $6 \mu \mathrm{M}$ greater concentrations of inorganic nitrogen than silicate (Townsend \& Thomas 2001). This is shown in Fig. 15 for all data collected on all 6 cruises in this study. From Fig. 15 we see even in January, near-zero silicate values with corresponding DIN values that are ca. $5 \mu \mathrm{M}$ greater. Silicate values continued to decline through April, after which the DIN concentrations also decreased such that in May plots of both nutrients tend to converge at the origin. Also in May, but especially in June, the silicate levels began to increase to between 0 and $6 \mu \mathrm{M}$, which probably corresponds to an increase in silicate regeneration. Thus, as diatoms take up both 

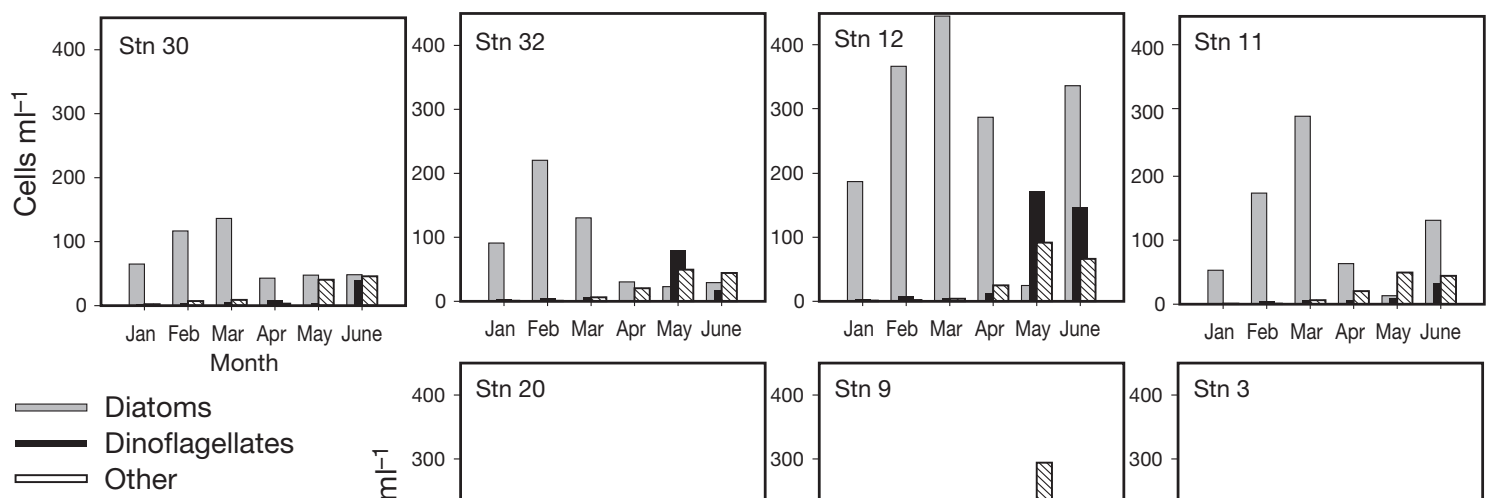

Fig. 9. Bar graphs of cell densities of 3 phytoplankton groups (diatoms, dinoflagellates and other flagellates [nanoflagellates]) at 7 stations (Fig. 1) on Georges Bank from January to June 1999

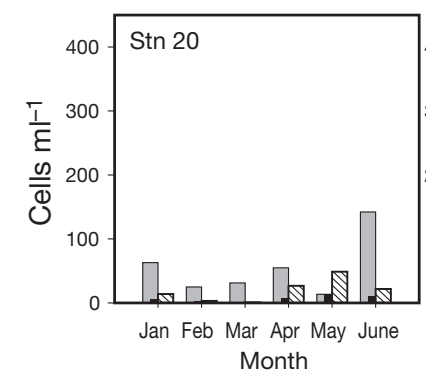

Jan Feb Mar Apr May June Jan Feb Mar Apr May June
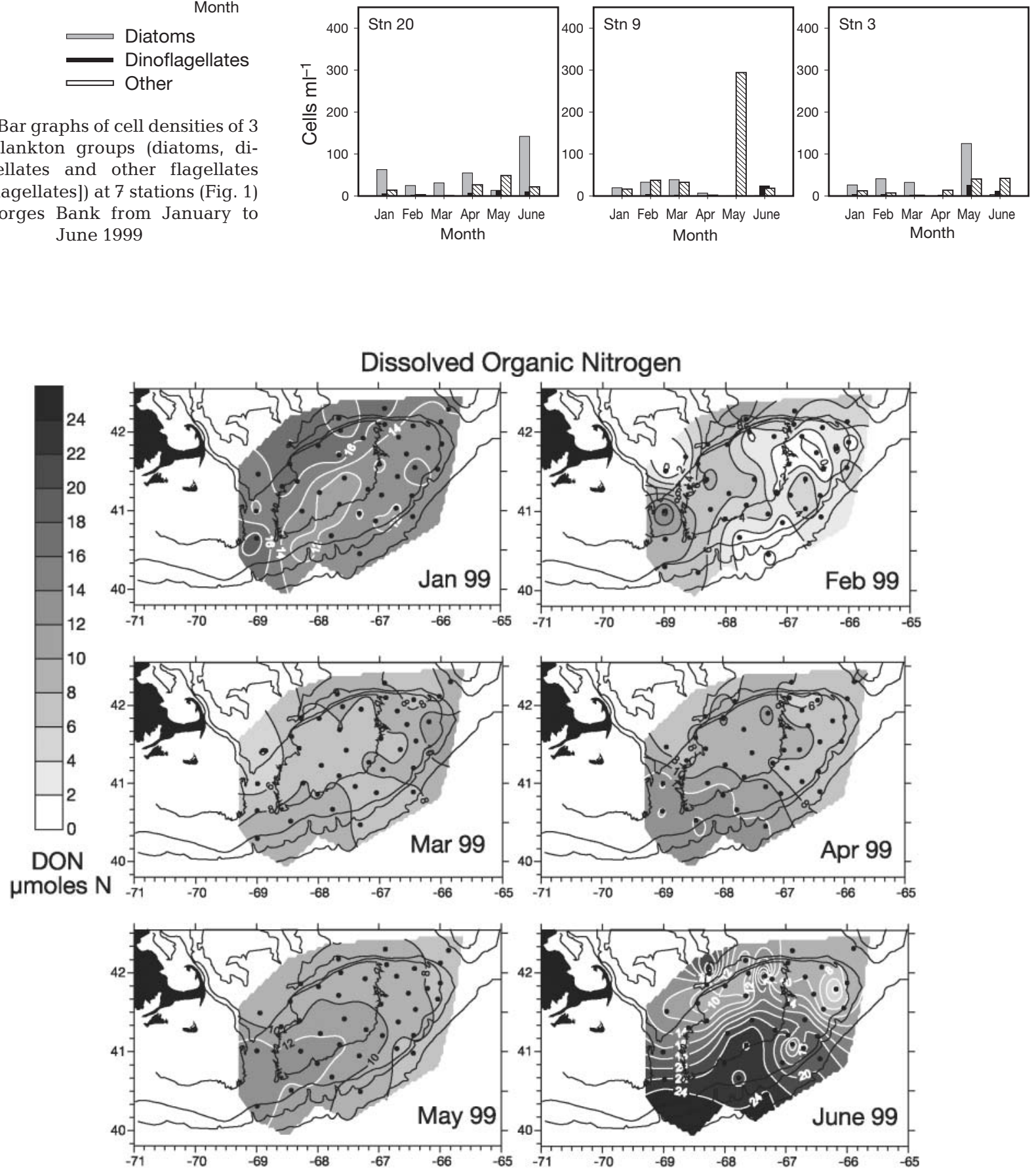

Fig. 10. Areal contour plots of dissolved organic nitrogen, presented as the average of 2 and $20 \mathrm{~m}$ depths at the standard stations, from January to June 1999. (•) stations 


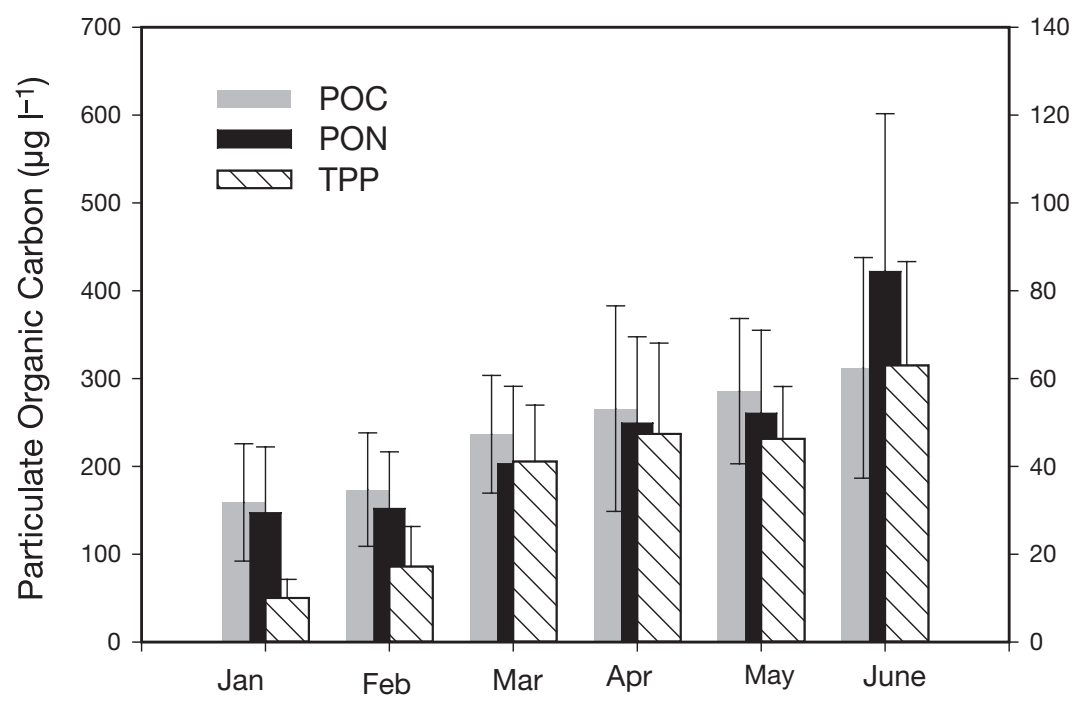

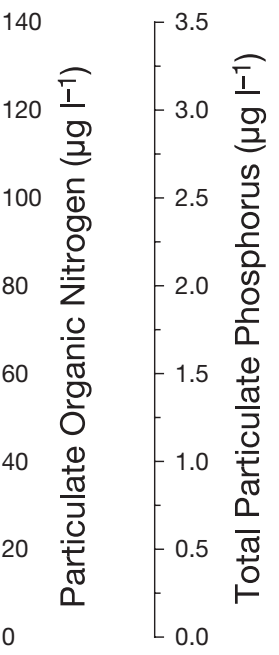

concentrations on the Bank continued through March, which was when we observed the highest concentrations of diatoms, and subsequently diatom cell densities decreased. By April, most of the Bank had become depleted in silicate. Curiously, however, we did not see an immediate and concomitant increase in the abundance of flagellates, which did not exhibit relatively high cell densities until May, suggesting relatively slow growth rates compared with diatoms, a need for higher light levels and/or significantly warmer water temperatures which are not reached until May.

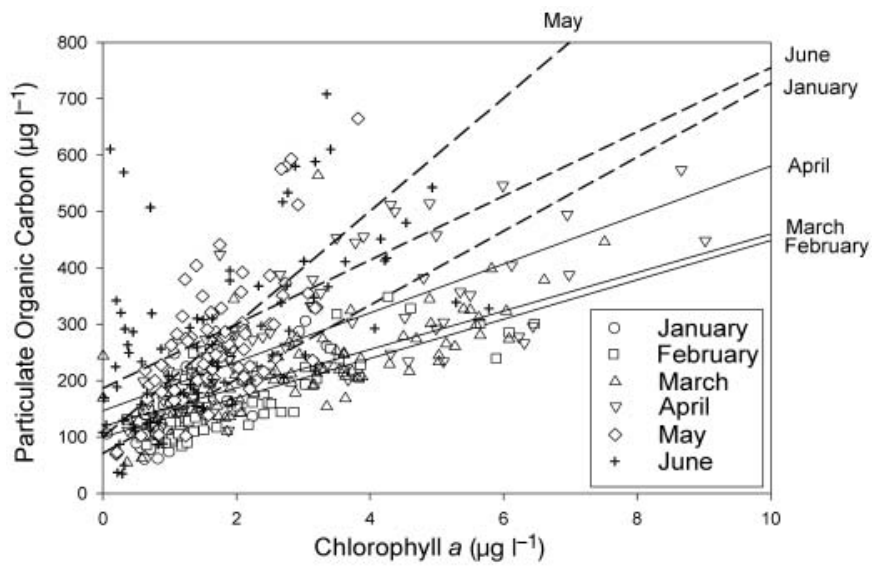

Fig. 13. Scatter plots of particulate organic carbon versus chlorophyll $a$ each month (January to June 1999) for 2 and $20 \mathrm{~m}$ depth samples at all standard stations (Stns 1 to 41); stations in deeper waters off Georges Bank (Stns 38, 34, 40, 29, 25, 39, 16 and 7) were excluded. Linear regression lines are plotted for each month, statistics are given in Tables 1 and 2. The May, June and January fitted regression lines are dashed, while the April, March and February lines are continuous, to indicate statistical differences of slopes between the 2 sets of regressions (Table 2) 
Table 1. Results of multiple comparison of $y$-intercepts for monthly regressions of particulate organic carbon versus chlorophyll $a$ in Fig. 13, using Tukey's HSD test (Zar 1999). Values of the $q$-distribution, sample size (in parentheses), and probability level are given.

\begin{tabular}{|c|c|c|c|c|c|c|}
\hline Month & Jan & Feb & Mar & Apr & May & Fun \\
\hline Jan & & $\begin{array}{c}3.07 \\
(\mathrm{n}=131)\end{array}$ & $\begin{array}{c}5.52 \\
(\mathrm{n}=128)\end{array}$ & $\begin{array}{c}7.76 \\
(\mathrm{n}=131)\end{array}$ & $\begin{array}{c}1.79 \\
(\mathrm{n}=150)\end{array}$ & $\begin{array}{c}3.77 \\
(\mathrm{n}=132)\end{array}$ \\
\hline Feb & $>0.50$ & & $\begin{array}{c}1.45 \\
(\mathrm{n}=147)\end{array}$ & $\begin{array}{c}1.97 \\
(\mathrm{n}=150)\end{array}$ & $\begin{array}{c}0.01 \\
(\mathrm{n}=149)\end{array}$ & $\begin{array}{c}2.65 \\
(\mathrm{n}=151)\end{array}$ \\
\hline Mar & 0.025 & $>0.50$ & & $\begin{array}{c}1.27 \\
(\mathrm{n}=147)\end{array}$ & $\begin{array}{c}1.21 \\
(\mathrm{n}=146)\end{array}$ & $\begin{array}{c}2.28 \\
(\mathrm{n}=149)\end{array}$ \\
\hline Apr & $<0.01$ & $>0.50$ & $>0.50$ & & $\begin{array}{c}2.63 \\
(\mathrm{n}=131)\end{array}$ & $\begin{array}{c}1.19 \\
(\mathrm{n}=151)\end{array}$ \\
\hline May & $>0.50$ & $>0.50$ & $>0.50$ & $>0.50$ & & $\begin{array}{c}5.44 \\
(\mathrm{n}=150)\end{array}$ \\
\hline Jun & 0.50 & $>0.50$ & $>0.50$ & $>0.50$ & 0.025 & \\
\hline
\end{tabular}

ginning to dissolve as a direct result of warmer water temperatures in May and June. Because of the shallow depths and the vigorous tidal mixing on the Bank, the silica is not lost by sinking as might be the case in deeper waters. There are 2 steps involved in the redissolution process, both of which are temperature-dependent. It is first necessary for the coating of organic material protecting the cell surface to be removed from the frustules by way of bacterial attack (Hecky et al. 1973), which would probably be a function of water temperature. Once the organic coating is removed, the dissolution of the silica is a direct function of water temperature (Kamatani 1982). The
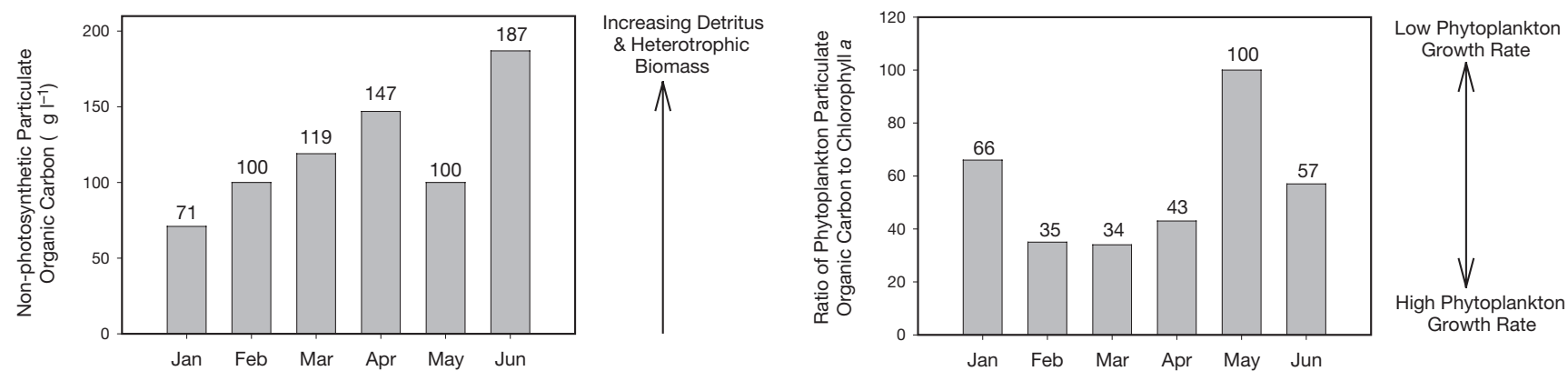

Fig. 14. Bar graphs of monthly averages of particulate organic carbon concentrations in 2 fractions: the non-living detritus and the heterotrophic plankton (left graph; values determined from the $y$-intercepts of each of the regression lines in Fig. 13), and monthly average ratios of phytoplankton particulate organic carbon to chlorophyll $a$, given as the slopes of the regression lines in Fig. 13 (right graph; relationship to phytoplankton growth rate is given)

Localized patches of increased silicate concentrations in the surface waters were observed in April at stations along the southern flank of the Bank (Fig. 6); these could either have been silicate pools remaining after the height of the winter-spring diatom bloom, or patches of regenerated silicate. By June, there were relatively broad areas of the northern part of the Bank in which silicate concentrations were elevated to $>2 \mu \mathrm{M}$. These results are similar to those recorded in 1997 (Townsend \& Thomas 2001) and strongly suggest re-dissolution of biogenic silica. That is, we presume that diatom frustules from the winter-spring bloom a few months earlier were be-
Table 2. Results of multiple comparison of slopes for monthly regressions of particulate organic carbon versus chlorophyll $a$ in Fig. 13, using Tukey's HSD test (Zar 1999). Values of the $q$-distribution, sample size (in parentheses), and probability level are given

\begin{tabular}{|c|c|c|c|c|c|c|}
\hline Month & Jan & Feb & Mar & Apr & May & Fun \\
\hline Jan & & $\begin{array}{c}8.65 \\
(\mathrm{n}=131)\end{array}$ & $\begin{array}{c}7.24 \\
(\mathrm{n}=128)\end{array}$ & $\begin{array}{c}5.04 \\
(\mathrm{n}=131)\end{array}$ & $\begin{array}{c}5.79 \\
(\mathrm{n}=150)\end{array}$ & $\begin{array}{c}0.89 \\
(\mathrm{n}=132)\end{array}$ \\
\hline Feb & $<0.001$ & & $\begin{array}{c}2.06 \\
(\mathrm{n}=147)\end{array}$ & $\begin{array}{c}1.86 \\
(\mathrm{n}=150)\end{array}$ & $\begin{array}{c}17.31 \\
(\mathrm{n}=149)\end{array}$ & $\begin{array}{c}7.81 \\
(\mathrm{n}=151)\end{array}$ \\
\hline Mar & $<0.001$ & $>0.50$ & & $\begin{array}{c}4.27 \\
(\mathrm{n}=147)\end{array}$ & $\begin{array}{c}20.68 \\
(\mathrm{n}=146)\end{array}$ & $\begin{array}{c}10.04 \\
(\mathrm{n}=149)\end{array}$ \\
\hline Apr & 0.025 & $>0.50$ & 0.20 & & $\begin{array}{c}13.89 \\
(\mathrm{n}=131)\end{array}$ & $\begin{array}{c}7.01 \\
(\mathrm{n}=151)\end{array}$ \\
\hline May & $<0.001$ & $<0.001$ & $<0.001$ & $>0.001$ & & $\begin{array}{l}2.48 \\
=150\end{array}$ \\
\hline Jun & $>0.50$ & $<0.001$ & $<0.001$ & $>0.001$ & $>0.50$ & \\
\hline
\end{tabular}



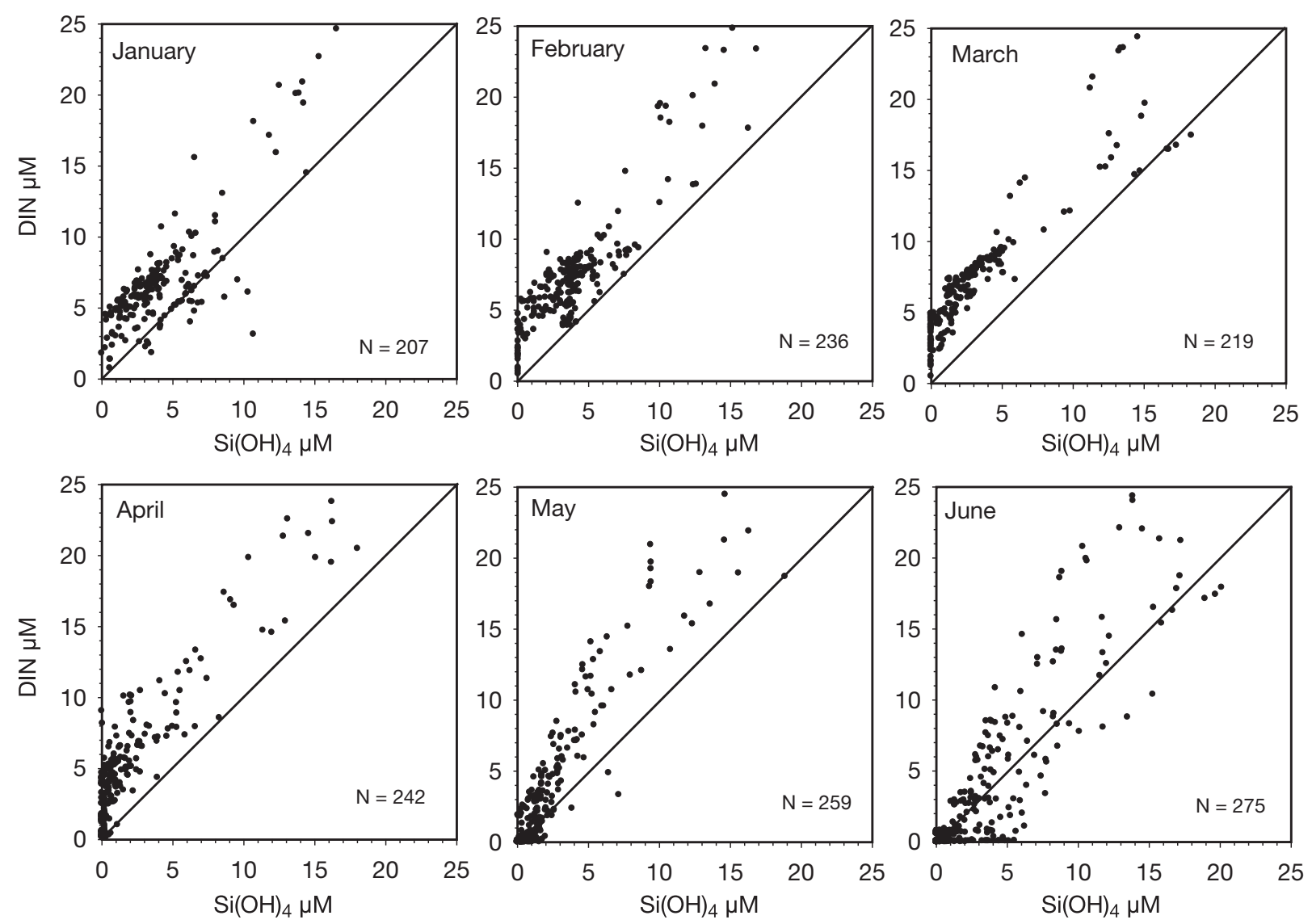

Fig. 15. Dissolved inorganic nitrogen (sum of $\mathrm{NO}_{3}, \mathrm{NO}_{2}$ and $\mathrm{NH}_{4}$ ) versus dissolved silicate $\left[\mathrm{Si}(\mathrm{OH})_{4}\right]$ at all stations and depths for the 6 survey cruises (in 1999). 1:1 line is plotted in each graph

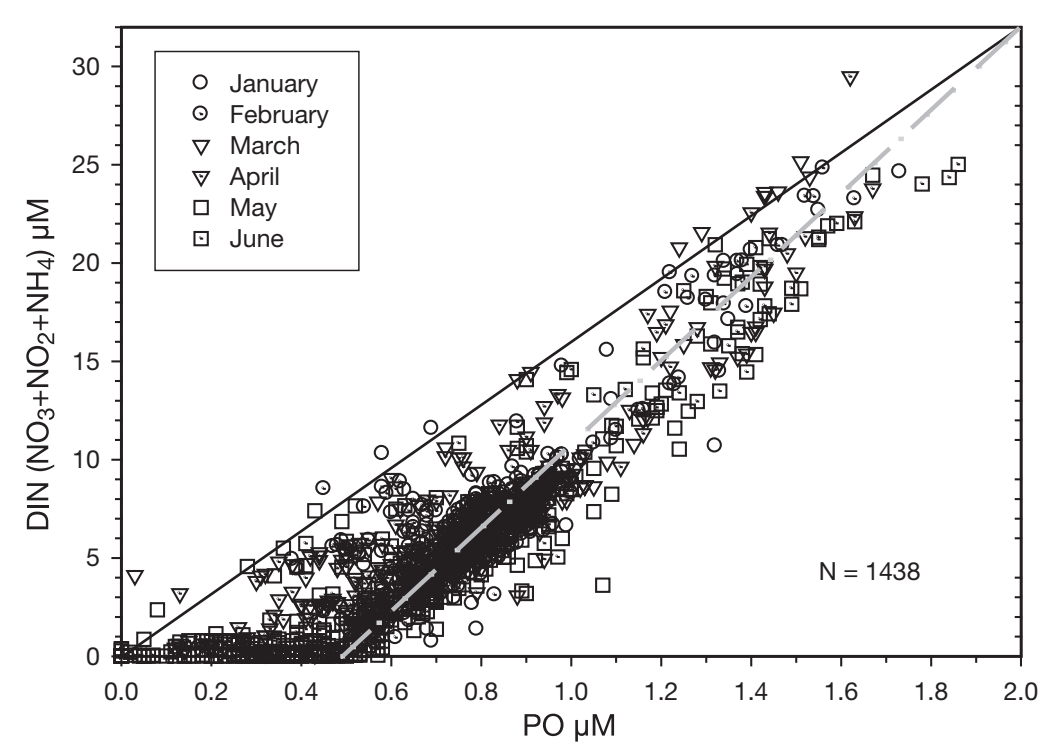

Fig. 16. Dissolved inorganic nitrogen (sum of $\mathrm{NO}_{3}, \mathrm{NO}_{2}$ and $\mathrm{NH}_{4}$ ) versus dissolved phosphate $\left(\mathrm{PO}_{4}\right)$ at all stations and depths for the 6 survey cruises.

Continuous line: 16:1 Redfield ratio; dashed line: visual fit to the data waters over most of Georges Bank remained at or below ca. $6^{\circ} \mathrm{C}$ from January to April, after which they warmed at a rate of about 3 to $4^{\circ} \mathrm{C}$ per month, supporting our assumption of temperaturedependent re-dissolution. We do not believe that the reappearance of dissolved silicate in May was the result of upwelling of deep-water nutrients into surface waters and subsequently onto the Bank. Although such a process could potentially renew silicate and other nutrients to the concentration levels seen in winter, and although it is certainly possible that phytoplankton could have rapidly taken up the new nitrogen making it difficult to detect, we did nor observe the concomitant signatures in temperature and salinity that would be expected. Stations that exhibited elevated surface (and subsurface) silicate 
concentrations in May and June most often had nitrate + nitrite concentrations of $<1 \mu \mathrm{M}$ (cf. Figs. 5, 6 \& 15), while potential deep-water sources beyond the Bank's edges had an excess of about 4 to $6 \mu \mathrm{M}$ more dissolved inorganic nitrogen than silicate (Fig. 15).

The depletion of DIN concentrations followed that of silicate, reaching concentrations of $<1 \mu \mathrm{M}$ over broad areas of the Bank in April (Fig. 5) at which point we presume that phytoplankton production as a whole became nitrogen-limited. Ammonium levels were only patchily distributed in April, and did not reach bank-wide concentrations higher than about $0.3 \mu \mathrm{M}$ until June (Fig. 8). Phosphate concentrations declined throughout the entire 6 mo period, but never fell to levels below our detection limits ( 0.1 to $0.2 \mu \mathrm{M}$; Fig. 7 ). Fig. 16 shows a plot of DIN versus phosphate for all data from all stations and sampling depths, illustrating that of the two nutrients, DIN, not phosphate, was the limiting nutrient from January to June. That is, nearly all the data points in Fig. 16 fall below the continuous line, indicating a N:P Redfield ratio of 16:1. However, in June, when DIN concentrations were at or near zero, we observed that phosphate levels also began to be depleted and crept toward zero. These dissolved inorganic nutrient analyses therefore strongly support the notion that primary production on Georges Bank becomes nutrient-limited very early in the year-by silicate in February and by DIN in April. Clearly, then, much of the primary production on Georges Bank is recycled production.

It is interesting to speculate here on the possible significance of the winter-spring diatom bloom on Georges Bank, especially in view of recent reports in the literature of the apparent toxic effects of diatoms on the reproductive success of copepods. Ban et al. (1997) reviewed earlier evidence and presented additional experimental results which showed that copepods fed diets of only diatoms produced eggs with low hatching success and nauplii with deformities. If fed a diet mixture that included flagellates, the diminished reproductive capacity disappeared. This subject is one of intense controversy (e.g. see Jonasdottir et al. 1998, Ianora et al. 1999) and as yet there is no consensus of opinion, but if the results of Ban et al. prove valid, it would imply that copepods on Georges Bank-inside the $60 \mathrm{~m}$ isobath, at least, where diatoms most clearly dominate-are unable to proliferate until flagellates become important components of the phytoplankton community in May and June. This indeed appears to be the case. Rather than exhibiting a springtime peak in zooplankton biomass concurrent with and shortly after the winter-spring bloom, the annual cycle of copepods on Georges Bank is reported to exhibit a biomass peak on about Calendar Day 151 (end of May/ beginning of June), to decline quickly over the next
2 mo (June and July), and then to decline more slowly to minimum biomass levels in December and January (Sherman et al. 1987). The peak in zooplankton biomass, then, corresponds to the May-June period when we saw a second burst in diatom production and increasing abundances of flagellates (Fig. 9), and this is the time in our study when nutrient limitation was most pronounced.

In recent studies on Georges Bank, Gifford and Sieracki (pers. comm.) have shown that one of the dominant copepods, Calanus finmarchicus, feeds mostly on heterotrophic protozoans rather than phytoplankton throughout the winter-spring period. How well $C$. finmarchicus fares before May and June, e.g. before we would expect protozoans to become abundant, or if there is any difference in vital rates between populations residing on the top of the Bank versus its flanks, where flagellates are more prominent, has yet to be demonstrated. In addition to the potential deleterious effects of a relatively pure diatom food source, the diatom bloom occurs during the time of coldest water temperatures, while the flagellates dominate at warmer temperatures after May. Zooplankton population growth rates in general would be expected to experience this additional negative effect brought about by cold water temperatures; an extreme example of this potential low-temperature effect has been discussed earlier with respect to the winter-spring diatom bloom in the Gulf of Maine (Townsend \& Cammen 1988). Finally, with respect to zooplankton, we observed in this study that overall particulate biomass, in units of organic carbon, nitrogen and total phosphorus, increased fairly steadily from January to June, reflecting an overall steady increase in micro- and nanoplanktonic food supply for a grazing zooplankton population. The lowest observed C:N ratios (Fig. 12), the greatest particulate biomass (Fig. 11), and a mixed assemblage of diatoms and flagellates in May and June (Fig. 9) would seem to support the notion that this early summer period is most important to secondary production in this shelf ecosystem. Almost paradoxically, this is also the period of nitrogen limitation of new primary production.

Despite questions about the nutritional significance of the winter-spring diatom bloom on Georges Bank, this prominent oceanographic event is normally thought to be very important to secondary production in other temperate shelf ecosystems. If our results from Georges Bank suggest that the diatom bloom production may not be directly channeled through a copepod-dominated zooplankton population until May and June, then might not that carbon be consumed by the benthos? Unfortunately, this is an area of research that has been neglected in recent years, and we simply do not know. Regardless of the ultimate fate of a diatom 
bloom, the contribution of the 1999 winter-spring bloom to total annual primary production on Georges Bank would at first appear to be very significant. We can calculate this contribution using the average decrease in total dissolved inorganic nitrogen on Georges Bank (approximated here by the area inside the $100 \mathrm{~m}$ isobath) from January to April. This decrease was approximately $5 \mu \mathrm{M}\left(=70 \mu \mathrm{g} \mathrm{N} \mathrm{I}^{-1}\right)$, which, using the Redfield ratio, converts to a potential 'new' primary production (discussed below) of $400 \mathrm{\mu gC}^{-1}$ over the 5 mo period from January to June. Ignoring any exports and imports of carbon or nitrogen across the bank's boundaries, and assuming an average depth of $60 \mathrm{~m}$ for the bank as a whole, this converts to about $24 \mathrm{~g} \mathrm{C} \mathrm{m}^{-2}$ new primary production over the $5 \mathrm{mo}$ period encompassing the spring bloom. This simple calculation does not include dissolved organic nitrogen, because our results suggest that although there is evidence of its uptake between January and February, by June the DON was back to very near the January levels (ca. $15 \mu \mathrm{M} \mathrm{N}$ ), resulting in no net change.

A new primary production of approximately $24 \mathrm{~g} \mathrm{C} \mathrm{m}^{-2}$ over the winter-to-summer period on Georges Bank is surprisingly small considering that the total annual primary production is estimated to be ca. $400 \mathrm{~g} \mathrm{C} \mathrm{m}^{-2} \mathrm{yr}^{-1}$ (O'Reilly et al. 1987). In addition to the wintertime accumulated nutrients, the remaining nutrient requirement for total primary production is met by a combination of upwelling fluxes of new nutrients (cf. Dugdale \& Goering 1967, Eppley \& Peterson 1979) as well as recycling in the well-mixed regions over most of the top of the Bank (Loder \& Platt 1985, O'Reilly et al. 1987, Walsh et al. 1987, Horne et al. 1996, Townsend \& Pettigrew 1997). Cross-isobath mixing and nutrient injections are thought to be most important along the northern flank of Georges Bank, where the topography is steepest and the hydrographic fronts are most pronounced (Loder et al. 1982, Loder \& Platt 1985, Loder \& Greenberg 1986, Horne et al. 1989, Townsend \& Pettigrew 1997). This provides a greater flux of nutrients to the northern edge, which is at the upstream end of the residual clockwise circulation pattern around the bank. These higher nutrient concentrations on the northern flank of Georges Bank were first observed by Pastuszak et al. (1982), based on data from a limited number of stations. Cross-isobath fluxes of nitrogenrich deeper waters have been calculated to explain new primary production of 50 to $100 \mathrm{~g} \mathrm{C} \mathrm{m}^{-2} \mathrm{yr}^{-1}$ (or 12 to $25 \%$ of the total estimated primary production; Townsend \& Pettigrew 1997). Thus, considering these continuous nutrient fluxes during the January to June period, which encompasses the winter-spring phytoplankton bloom, new production is more likely somewhere between 44 and $65 \mathrm{~g} \mathrm{C} \mathrm{m}^{-2} \mathrm{yr}^{-1}$ (e.g. $24 \mathrm{~g} \mathrm{C} \mathrm{m}^{-2}$ $\mathrm{yr}^{-1}$ plus five-twelfths of 50 to $100 \mathrm{~g} \mathrm{C} \mathrm{m}^{-2} \mathrm{yr}^{-1}$ ). As we have already argued, this exercise demonstrates that in order to explain high rates of primary production on Georges Bank we must conclude that, in summer, nutrient recycling is important in the bank's central portions, with new primary production occurring along its edges. Such a tentative conclusion is consistent with the change we observed from spring to summer in the taxonomic composition of the phytoplankton.

The summertime planktonic ecosystem on Georges Bank would seem to be one of greater nutrient recycling on the Bank's central portions, and more new primary production along the edges, as just discussed. The micro- and nanoheterotrophic components of the plankton community in this scenario are therefore important in nutrient cycling, but their abundances are not immediately evident from our cell counts, which were based on Lugol-preserved samples, thus making pigments difficult to identify. However, we can deduce some qualitative indications of their relative contributions to total biomass based on our analyses of particulate carbon, nitrogen and phosphorus (Fig. 11), the particulate organic C:N ratios (Fig. 12) and ratios of POC to chlorophyll (Fig. 13).

Assuming that the $y$-intercept of the POC:chlorophyll ratio in Fig. 13 corresponds to the standing stock of organic carbon in the detritus and heterotrophic plankton, we see that there is a general increase in that particulate fraction of the seston from January to June (Fig. 14). The generally-decreasing trend in the C:N ratios (Fig. 12) would suggest that the increases shown in Fig. 14 are more the result of living heterotrophs than detritus. It is probable, therefore, that a significant fraction of the flagellates we observed in May and June were heterotrophic, and may have been important in nutrient recycling. Quantitative estimates of the relative proportions of autotrophs and heterotrophs are lacking, however. Finally, the carbon-to-chlorophyll ratios of the phytoplankton in May and June were significantly higher than in February, March and April, indicating a lower phytoplankton growth rate in May and June. Whether a lower phytoplankton growth rate in early summer is offset by an increased biomass also remains unknown. Additional work in this area is clearly required before these interesting and potentially important questions can be addressed.

In summary, we observed that the winter-spring phytoplankton bloom in the Georges Bank region may begin as early as January. Likewise, there may be low but significant year-round primary production on the bank at a rate sufficient to impede the complete replenishment and buildup of new nutrients via winter mixing and local regeneration. The winter-spring bloom was well pronounced over the central portions of the Bank, and became silicate-limited as early as February; later in the spring, nitrate + nitrite became 
limiting. Regeneration of silicate became apparent in May and June, and appeared to promote a second burst of diatoms along with increasing abundances of other non-diatom phytoplankton groups. Total microand nanoplankton biomass and nutritional quality of that biomass increased from January to June. Zooplankton production would seem to be dependent on increases in the mixed planktonic assemblage forage during the May-June period.

Acknowledgements. We thank the captains and crew of the RV's 'Albatross IV' and 'Oceanus' for their assistance at sea, and we gratefully acknowledge the assistance of the many Globec Project scientists, assistants and volunteers who helped on all cruises. Special thanks go to Keska Kemper, Abby Deitz, Annette Brickley and Megan DiPirro of the University of Maine for work at sea and in the laboratory. We thank David Mountain and Maureen Taylor of the Northeast Fisheries Science Center, Woods Hole, for use of the CTD data. Jeff Turner of the University of Massachusetts, Dartmouth, kindly confirmed identification of the genus Pyramimonas. Additional assistance at sea was generously provided by Regina Pfiestmuller, Matthew Cieri, Wayne Peterson, Melanie Sorensen, Joanne Lardi and John Kieser, to whom we extend our sincere appreciation. Special thanks go to all of our Globec colleagues for their spirited and constantly stimulating discussions. Finally, we thank Jerry Cura and 2 anonymous reviewers for valuable comments that significantly improved an earlier draft of this paper. This work was supported by grants from NSF (OCE-9806712) and NOAA's (NA960P0001 and NA960P0004) US Globec Program.

\section{LITERATURE CITED}

Backus RH (ed) (1987) Georges Bank. MIT Press, Cambridge, MA

Ban S and 21 others (1997) The paradox of diatom-copepod interactions. Mar Ecol Prog Ser 157:287-293

Brzezinski MA (1985) The Si:C:N ratio in marine diatoms: interspecific variability and the effect of some environmental variables. J Phycol 21:347-357

Cohen EB, Grosslein DD (1987) Production on Georges Bank compared with other shelf ecosystems. In: Backus RH (ed) Georges Bank. MIT Press, Cambridge, MA, p 383-391

Cura JJ (1987) Phytoplankton. In: Backus RH (ed) Georges Bank. MIT Press, Cambridge, MA, p 213-218

Draxler AFJ, Matte A, Waldhauer R, O'Reilly JE (1985) Nutrient distributions for Georges Bank and adjacent waters in 1979. NOAA Tech Rep NMFS 32:34

Dugdale RC, Goering JJ (1967) Uptake of new and regenerated forms of nitrogen in primary productivity. Limnol Oceanogr 12:196-206

Elser JJ, Dobberfuhl DR, MacKay NA, Schampel JH (1996) Organisms size, life history, and N:P stoichiometry. BioScience 46:647-684

Eppley RW, Peterson BJ (1979) Particulate organic matter flux and planktonic new production in the deep ocean. Nature 282:677-680

Hecky RE, Mopper K, Kilham P, Degens ET (1973) The amino acid and sugar composition of diatom cell walls. Mar Biol 19:323-331

Horne EPW, Loder JW, Harrison WG, Mohn R, Lewis MR, Irwin B, Platt T (1989) Nitrate supply and demand at the Georges Bank tidal front. Sci Mar 53:145-158
Horne EPW, Loder JW, Naimie CE, Okey NS (1996) Turbulence dissipation rates and nitrate supply in the upper water column on Georges Bank. Deep-Sea Res Part II Top Stud Oceanogr 43:1683-1712

Ianora A, Antonio M, Poulet SA (1999) Are diatoms good or toxic for copepods? Reply to comment by Jonasdottir et al. Mar Ecol Prog Ser 177:305-308

Jonasdottir SH, Kiørboe T, Tang KW, St. John M, Visser AW, Saiz E, Dam HG (1998) Role of diatoms in copepod production: good, harmless or toxic? Mar Ecol Prog Ser 172: 305-308

Kamatani A (1982) Dissolution rates of silica from diatoms decomposing at various temperatures. Mar Biol 68:91-96

Kemper K (2000) Dynamics of silicate and the late spring phytoplankton community on Georges Bank, May and June 1998. MS thesis, University of Maine, Orono

Loder JW, Greenberg DA (1986) Predicted position of tidal fronts in the Gulf of Maine region. Contin Shelf Res 6: $397-414$

Loder JW, Platt T (1985) Physical controls on phytoplankton production at tidal fronts. In: Gibbs PE (ed) Proceedings of the Nineteenth European Marine Biology Symposium. Cambridge University Press, Cambridge, UK, p 3-21

Loder JW, Wright DG, Garrett C, Juszko BA (1982) Horizontal exchange on central Georges Bank. Can J Fish Aquat Sci 39:1130-1137

O'Reilly JE, Evans-Zetlin C, Busch DA (1987) Primary production. In: Backus RH (ed) Georges Bank. MIT Press, Cambridge, MA, p 220-233

Paasch E (1973) Silicon and the ecology of marine plankton diatoms. II. Silicate uptake kinetics in five diatoms species. Mar Biol 19:262-269

Parsons TR, Maita Y, Lalli CM (1984) A manual of chemical and biological methods for seawater analysis. Pergamon, Press Ltd, Oxford

Pastuszak M, Wright WR, Patanjo D (1982) One year of nutrient distribution in the Georges Bank region in relation to hydrography. J Mar Res 14:525-542

Riley GA (1941) Plankton studies. IV. Georges Bank. Bull Bingham Oceanogr Collect Yale Univ 7:1-73

Sherman K, Smith WG, Green JR, Cohen EB, Berman MS, Marti KA, Goulet JR (1987) Zooplankton production and the fisheries of the Northeast Shelf. In: Backus RH (ed) Georges Bank. MIT Press, Cambridge, MA, p 268-282

Solórzano L, Sharp JH (1980a) Determination of total dissolved nitrogen in natural waters. Limnol Oceanogr 25: $751-754$

Solórzano L, Sharp JH (1980b) Determination of total dissolved phosphorus and particulate phosphorus in natural waters. Limnol Oceanogr 25:754-758

Townsend DW, Cammen LM (1988) Potential importance of the timing of spring plankton blooms to benthic-pelagic coupling and recruitment of juvenile demersal fishes. Biol Oceanogr 5:215-228

Townsend DW, Pettigrew NR (1997) Nutrient limitation of secondary production on Georges Bank. J Plankton Res 19:221-235

Townsend DW, Spinrad RW (1986) Early spring phytoplankton blooms in the Gulf of Maine. Cont Shelf Res 6:515-529

Townsend DW, Thomas AC (2001) Winter-spring transition of phytoplankton chlorophyll and inorganic nutrients on Georges Bank. Deep-Sea Res Part II Top Stud Oceanogr 48:199-214

Townsend DW, Xu J (1997) Phytoplankton chlorophyll, nutrients and light attenuation studies. In: Cruise Report, R/V 
Oceanus Cruise 298, U.S. Northwest Atlantic/Georges Bank Study. Woods Hole Oceanographic Institution, Woods Hole, MA, p 18-26

Townsend DW, Cammen LM, Holligan PM, Campbell DE, Pettigrew NR (1994) Causes and consequences of variability in the timing of spring phytoplankton blooms. Deep-Sea Res Part I Oceanogr Res Pap 41:747-765

Walsh JJ, Whitledge TE, O'Reilly JE, Phoel WC, Draxler AF (1987) Nitrogen cycling on Georges Bank and the New York shelf: a comparison between well-mixed and seasonally stratified waters. In: Backus RH (ed) Georges Bank. MIT Press, Cambridge, MA, p 234-246

Editorial responsibility: Kenneth Sherman (Contributing Editor), Narragansett, Rhode Island, USA
Whitledge TE, Veidt DM, Mallow SC, Patton CJ, Wirick CD (1986) Automated nutrient analyses in seawater. Publ Brookhaven Natl Lab (BNL) NY 38990:

Wiebe PM, Beardsley RC (eds) (1996) Physical-biological interactions on Georges Bank and its environs. Deep-Sea Res Part II Top Stud Oceanogr 43(7/8):1437-2005

Wiebe PM, Beardsley RC, Bucklin AC, Mountain DG (eds) (2001) Coupled biological and physical studies of plankton populations: Georges Bank and related North Atlantic regions. Deep-Sea Res Part II Top Stud Oceanogr 48(1-3):1-684

Zar JH (1999) Biostatistical analysis. 4th edn. Prentice Hall, Upple Saddle River, NJ

Submitted: August 8, 2000; Accepted: February 22, 2001 Proofs received from author(s): February 12, 2002 